\title{
Business in The New Normal Era:
}

\author{
Disclosure of Accounting Practice at MSMEs in Malang City
}

\author{
Dhika Maha Putri*, Slamet Fauzan, Masculine Muhammad \\ Muqorobin \\ Faculty of Economics \\ Universitas Negeri Malang \\ Malang, Indonesia \\ *dhika.maha.fe@um.ac.id, slamet.fauzan.fe@um.ac.id, \\ masculine.muhammad.fe@um.ac.id
}

\author{
Mohd Rizal Palil \\ Faculty of Economics \\ Universiti Kebangsaan Malaysia (UKM) \\ Kuala Lumpur, Malaysia \\ mr_palil@ukm.edu.my
}

\begin{abstract}
The Covid-19 pandemic currently requires business in various fields (including MSMEs) to adapt to the new normal life. This also has an impact on maximizing the use of accounting as the main finance media. Given the large contribution of the MSMEs activities, the owner of business should develop adequate accounting process to maintain the supervision of the business activities. Through the data collected by interviews and focus group discussions, this study describes the understanding and practice of accounting at MSMEs in Malang City. In fact, MSMEs don't understand much about accounting and still find it difficult to practice it in financial management. This condition occurs because there are a very few guidelines that describe accounting practices in MSMEs. The results of the study suggest the need of an accounting practice model and guidelines according to the conditions of the MSME in the new normal era. The implementation of accounting is believed to be able to improve the quality of MSME financial management. Good financial management is very important, given the difficulty of a business surviving in the era of the Covid19 pandemic
\end{abstract}

Keywords-accounting, financial management, MSMEs, practice, guidelines

\section{INTRODUCTION}

Micro, Small, Medium enterprise is one of economic activities that is quite popular in the community as the grassroots support of welfare. Some call this type of economic activity as the shadow economy [1], as it is not legally registered [2], but positively contributes to the national economic [3]. Other also refer to it is as informal economic sector. This economic sector is growing in urban and rural communities [4]. Typology and geographical features of the community do not hinder the Micro, Small, Medium Enterprises (MSMEs) to root among them [5]. The informal economic activity is proven sustainable amidst economic crisis in Indonesia [6], as for some reasons it is not significantly affected by global economic issues. During the Covid-19 pandemic like now, global trade is quite difficult for every country. Therefore, the State must be able to meet its own needs. In this case, the use of domestic products is an alternative in meeting needs. In addition, local consumption can keep the economy moving. MSMEs as managers of domestic products are an important sector, especially in critical times like today.

The strength of informal economic sector in the form of MSMEs has gained attention from experts to further investigate the essence of this economic activity. The characteristic mentioned above, that informal economic sector is the shadow economic [1], not registered [2], but able to support the public economic [3], are included in the general conception. This activity, in fact, can provide job opportunities for the community, not only for the owners, but also for the worker class who do not own capital [7]. Many of them are vulnerable since they do not have any access to capital [8]. So, the only way to save their financial conditions is through this informal sector along with all its consequences.

The Coronavirus is a virus that was first discovered in Wuhan, Hubei, China in 2019 and has spread to various parts of the world, so the virus is named covid19 [9]. WHO itself has determined that the coronavirus has become a global pandemic along with the increasing number of patients identified with the coronavirus [10]. Thus, the coronavirus is a very dangerous virus and can attack. Coronavirus Pandemic has a significant impact on various sectors of life, one of which is the economic sector.

As a result of the spread of the corona virus, the Government has instructed that all community activities be carried out with health protocols or social distancing that bring people into the new normal era. This, of course, affects the survival of MSMEs. The all-new condition of Covid-19 and weak adaptability have made people's purchasing power decrease. Therefore, business management must be carried out more efficiently and effectively to match the income earned. The strength of MSMEs to continue to survive cannot be separated from a weapon that can be used for business management. The weapon in question is a financial report. Financial accounting or reporting cannot be denied is something that must be done by all business entities. Financial reporting itself is useful for underlying decision making, even financial reporting is also useful for parties outside the business such as creditors and investors. 
Basically, the rapid development of MSMEs has been responded positively by the government and the Indonesian Institute of Accountants with the issuance of SAK ETAP (Entity without Public Accounting) which is intended for companies that are not listed on the stock exchange and are not bank companies, not insurance companies, not brokerage companies or traders. securities, not a pension fund company, not a mutual fund company, not an investment bank company in order to make financial reports easier. In 2018 IAI issued another SAK EMKM (Micro, Small and Medium Enterprises) which aims to separate MSMEs and other entities without public accounting. SAK EMKM has been proven to improve the financial quality of MSMEs. This is because the manager knows better about the position and financial health of his business. Knowing the financial health position of their business allows business owners to adopt the most profitable plan or strategy for their business. It can be concluded that financial reports are very important for the realization of the progress of SMEs. Some of the benefits of applying accounting for MSMEs are: (1) as a planning tool; (2) as a means of financial means; (3) see the amount of profit and loss; (4) facilitate obtaining credit; (5) as a decision maker; and (6) as an evaluation tool.

Unfortunately, the importance of financial reports has not been matched by its implementation by MSMEs. This is especially true for MSMEs in Malang. Through short interviews conducted online with owners, it was found that not many MSMEs had made financial reports. For MSMEs, financial reporting is still considered a difficult thing to implement because it takes time and is considered not very useful for their business. This study tries to reveal how the implementation of financial reporting. With this research, it is hoped that the pattern of the use of financial reporting at MSMEs can be translated comprehensively so that it can be seen what and why MSMEs in Malang City do not make financial reports.

\section{METHODS}

This research was conducted through qualitative approach using study case. The types of data were secondary and primary data. The secondary data were collected through literature study from books, research, and other sources relevant to this study, while the primary data were collected through interview and FGD (Forum Group Discussion) with the informants who are the owners of MSMEs in Malang City. Teng et al. (2019) conducted an online survey to get the insight regarding the perspectives on accounting to MSMEs owners in Malang City. This study was performed through direct interviews and FGD with MSMEs owners in Malang City, so it could provide in-depth answer to the research objective by collecting the information related to accounting perspectives they had in mind. Moreover, the results of the interview could be used as a guidance in making accounting record needed by MSMEs owners in Malang city.

This study was conducted during the pandemic; therefore, the data collection with interviews and FGD was entirely carried out online. Some informants were chosen by purposive sampling from each region in Malang City and adjusted to the types of their businesses which were MSMEs engaged in service, trade and manufacture. There were 10 informants selected from each region in Malang City of service, trade, and manufacture sectors. The inclusive criteria were business owner in service, trade, and manufacture business represented by 2 informants from each sector. It was expected that the information obtained from this study was linear and in accordance with the research objective and urgency. Data analysis in this study is using an interactive model revealed by Miles and Huberman (1992). The components of the interactive model, namely; (1) data collection; (2) data reduction; (3) data presentation; and (4) drawing conclusions.

\section{RESUltS AND Discussion}

This research was conducted by conducting in-depth interviews with MSMEs owners in Malang City. The total participants of this study were 10 MSMEs in Malang City which engaged in all fields, from Food and Beverage, crafts, to fashion. The results of this study concluded that there are still many MSMEs in Malang City that do not do financial reporting, even though most of them are aware of the importance of financial reporting. Most of them argued that making financial reports took up their time and energy which could have been used to carry out business activities. This is of course an interesting finding and fact, because basically MSME owners know the benefits of financial reporting, but they don't want to make it.

"It's complicated to use reporting, this is my money" (N1)

"I know that reporting is important, it just takes up my time so I don't use it" (N2)

"Yes, I only knew that the money was recorded in and out" (N3)

Several things that make business owners reluctant to make financial reports, are: (1) lack of knowledge about MSME financial reporting; (2) time is lost by the owner to prepare financial reports; (3) there is no reporting obligation because it uses its own capital.

"The financial reports training only for one to two days, so its not adequate" (N1)

"I graduated from accounting major, but it's very different between campus study and the reality. I know that reports is important, but when I make a financial report I can lose my time" (N2)

"This is useful, but we need training in making financial reports from zero to $100 \% "$ (N4)

By conducting interviews with MSMEs owners in Malang City, it can be obtained information that it is not enough to provide materials and modules because there are so many materials that make it difficult for MSME owners to accept 
them. They are more likely to provide guidance from academics for the preparation of financial reports. Of course, the guidance will be combined with the characteristics of each MSMEs, because we also realize that practice in the field is not as complex as what we learn in lectures. It is hoped that the integration of SAK EMKM with real reality in the field will make it easier for MSME owners to make financial reports and determine their business strategies.

"Wow, if there is guidance, Alhamdulillah, it is even good for us to understand it" (N4)

"Especially if the guidance it's easy and automatic so we can save our time" (NI)

"It's good if there is guidance, if I can report my finances later, I can make a reference for taking out a capital loan" (N3)

This guidance lasts approximately 30 days or one month of the accounting cycle, because it is expected that MSMEs can make monthly financial reports. Why monthly, because the sales cycle is relatively short to make the financial cycle also short. This short sales cycle makes MSME owners have to be able to develop their strategies more flexibly. This strategy can be prepared if the owners have financial reports that show the financial position of their business.

Guidance is filled with a basic understanding of financial reporting because most of them are unfamiliar with financial reporting. For various types of financial reports, the supervisor will adjust to the needs of each owner. In the process of making this financial report, the supervisors have used a spreadsheet which aims to make it easier for MSME owners. Later, MSME owners only need to enter their transactions and their financial data, then the results of their real financial reports will automatically appear. It is hoped that this can be accepted and applied by MSMEs in Malang, so that MSMEs can continue to develop and be a going concern.

\section{CONCLUSION}

The importance of financial reporting has basically been recognized by MSME actors in Malang City, but these MSME actors chose not to do financial reporting because according to them, the capital they have is private capital which has no accountability to external parties. In addition, the lack of knowledge in making financial reports is another reason for MSMEs not to do financial reporting. Based on this, the researcher tries to provide guidance in making financial reports, especially in MSMEs Malang City. Through the data that has been collected through interviews, various kinds of findings are obtained such as, lack of knowledge, lack of time to prepare financial reports, and difficulty in the process of preparing financial reports.

After we studied the problems that arose in MSMEs in Malang, then we carried out PAR (Participatory Action Research) to provide guidance in making financial reports. In this guidance, the materials are combined with the needs of each MSMEs. Coaching time is made 30 days or one month of accounting cycle so that MSME owners can more easily determine what strategies they will take for the continuity of their business

\section{REFERENCES}

[1] B. Suyanto, Sosiologi Ekonomi: Kapitalisme dan Konsumsi di Era Masyarakat Post-Modernisme. Jakarta: Kencana, 2013.

[2] J. W. Webb, G. D. Bruton, L. Tihanyi, and R. D. Ireland, "Research on entrepreneurship in the informal economy: Framing a research agenda," J. Bus. Ventur., vol. 28, no. 5, pp. 598-614, 2013, doi: 10.1016/j.jbusvent.2012.05.003.

[3] C. Elgin and F. Erturk, "Informal economies around the world measures, determinants and consequences," Eurasian Econ. Rev., vol. 9, no. 2, pp. 221-237, 2019, doi: 10.1007/s40822-018-0105-5.

[4] L. A. Perguna, I. H. Al Siddiq, and Irawan, "Desa Membangun UMKM: Pendampingan UMKM berbasis Village Driven Development dalam Penguatan Ekonomi Warga Di Desa Gogodeso Kabupaten Blitar,' Engagem. J. Pengabdi. Kpd. Masy., vol. 3, no. 2, pp. 217-230, 2019, doi: 10.29062/engagement.v3i2.62.

[5] Y. Kumar, G. Pandey, A. P. W. Wordsworth, and J. S. Chauhan, Reflecting on India's development: Employment, skill and health. Springer Singapore, 2018

[6] T. T. H. Tambunan, "The Indonesian Experience with Two Big Economic Crises," Mod. Econ., 2010, doi: 10.4236/me.2010.13018.

[7] L. Martínez, J. R. Short, and D. Estrada, "The urban informal economyStreet vendors in Cali, Colombia," Cities, vol. 66, pp. 34-43, 2017, doi: 10.1016/j.cities.2017.03.010.

[8] M. Athaide and H. K. Pradhan, "A model of credit constraint for MSMEs in India," Small Bus. Econ., no. 2018, 2019, doi: 10.1007/s11187-019-00167-4.

[9] M. S. Arshad et al., "Coronavirus disease (COVID-19) and immunity booster green foods: A mini review," Food Sci. Nutr., vol. 8, no. 8, pp 3971-3976, Aug. 2020, doi: 10.1002/fsn3.1719.

[10] S. Paramita, A. Rahmadi, R. Isnuwardana, and R. A. Nugroho, "Onemonth Progress of COVID-19 Cases in East Kalimantan, Indonesia," Open Access Maced. J. Med. Sci., vol. 8, no. T1, pp. 45-50, 2020. 